OPEN ACCESS

Edited by:

Lara Lengel,

Bowling Green State University,

United States

Reviewed by:

Wu Zhou,

Huazhong University of Science and

Technology, China

Dusan Radivoje Mitic,

University of Belgrade, Serbia

*Correspondence:

Yaodong Gu

guyaodong@hotmail.com

Specialty section:

This article was submitted to

Public Health Policy,

a section of the journal

Frontiers in Public Health

Received: 27 May 2020 Accepted: 19 November 2020 Published: 10 December 2020

Citation:

Cen $X$, Sun D, Rong $M$, Fekete $G$ Baker JS, Song Y and Gu Y (2020)

The Online Education Mode and Reopening Plans for Chinese Schools

During the COVID-19 Pandemic: A

Mini Review.

Front. Public Health 8:566316. doi: $10.3389 /$ fpubh.2020.566316

\section{The Online Education Mode and Reopening Plans for Chinese Schools During the COVID-19 Pandemic: A Mini Review}

\author{
Xuanzhen Cen ${ }^{1}$, Dong Sun ${ }^{1}$, Ming Rong ${ }^{1}$, Gusztáv Fekete ${ }^{2}$, Julien S. Baker ${ }^{3}$, Yang Song ${ }^{4}$ \\ and Yaodong $\mathrm{Gu}^{1 *}$ \\ ${ }^{1}$ Faculty of Sports Science, Ningbo University, Ningbo, China, ${ }^{2}$ Savaria Institute of Technology, Eötvös Loránd University, \\ Szombathely, Hungary, ${ }^{3}$ Department of Sport and Physical Education, Hong Kong Baptist University, Hong Kong, China, \\ ${ }^{4}$ Faculty of Engineering, University of Szeged, Szeged, Hungary
}

Recently, an unprecedented coronavirus pandemic has emerged and has spread around the world. The novel coronavirus termed COVID-19 by the World Health Organization has posed a huge threat to human safety and social development. This mini review aimed to summarize the online education mode and plans for schools to resume full-time campus study in China during COVID-19. Chinese schools have made significant contributions to the prevention and control of the transmission of COVID-19 by adopting online learning from home. However, normal opening and classroom teaching have been affected. For education systems at all levels, online education may be an effective way to make up for the lack of classroom teaching during the epidemic. To protect staff and students from COVID-19, the timing of students returning to full-time campus study needs to be considered carefully. Reviewing and summarizing of the Chinese education system's response to the virus would be of great value not only in developing educational policy but also in guiding other countries to formulate educational countermeasures.

Keywords: online education, back-to-school, corona virus disease, novel coronavirus, reopening time

\section{INTRODUCTION}

Since December 2019, atypical pneumonia has been widely spreading throughout the world (1), and the number of recorded cases has increased dramatically. On February 11, 2020, the International Committee on Taxonomy of Viruses (ICTV) announced that the new virus responsible for atypical pneumonia would be named "severe acute respiratory syndrome coronavirus 2 (SARS-CoV-2)." The name created unintended fear in the public, especially in Asia which was affected badly by SARS in 2003. From a risk communications perspective, the World Health Organization (WHO) has begun announcing "the COVID-19 virus" as the name of the new virus when communicating and providing updates for the public (2). This new outbreak has impacted massively on worldwide populations, especially on health and economy toll globally (3). The outbreak of COVID-19 has also resulted in huge health and economical toll globally. Modeling and analysis have revealed that even if the outbreak is effectively controlled, the global economy will experience a massive decline (4). In China, for example, COVID-19 spread rapidly from a single city to the whole country in just 30 days since the outbreak (5). This rate of transmission is alarming, and the transmission seems to be taking place via individuals in close contact. Studies have shown that COVID-19 has a higher 
susceptible population, is more widespread, and is more contagious than the SARS coronavirus (6). As of May 26, 2020 , the total number of confirmed cases in China reached 84,543 . Worldwide, the number of recorded cases has reached $5,505,801(7)$.

It should be mentioned, that the outbreak coincided with the traditional Spring Festival, which is the most important festival of the year in China. During this time, several hundred million people move and relocate, and residents and tourists mostly choose to travel by using crowded planes, trains, and buses (8). This means that infected individuals may have close contact with other individuals for long periods when traveling long distances (9), which leads that the spread of COVID-19 was hardly controlled. The rapid spread of the epidemic which is due in part to large population movements is considered one of the main reasons for the large-scale transmission of the disease $(9,10)$. Fortunately, schools were closed during the Chinese Lunar New year that enabled the government to carefully consider measures needed for schools to protect staff and students. China has a large and dense student population located in both urban and rural areas. According to statistics recorded in 2018 (11), there are 518.8 thousand schools of all levels and types in China, with 276 million students and 16.7 million full-time teachers. Social isolation is undoubtedly effective in reducing virus transmission, although COVID-19 rarely affects children in asymptomatic cases, and infection and virus transmission characteristics are not clear in this group (12).

At present, the most important method of containment during the COVID-19 Pandemic is isolation (13). As the most severely affected area in China, Wuhan city was in lockdown on January 23, 2020. The subsequent spread of the COVID19 virus led to the imposition of a cordon sanitaire, limiting the population movements among 16 cities in Hubei province and affecting more than 50 million people (13). And this restriction has gradually expanded to most areas of China. Public transport including planes, high-speed trains and subways, entertainment venues including cinemas, bars and amusement parks, and schools at all levels were forced to close, leading to an unprecedented nationwide lockdown in China $(8,13)$. Despite quarantine representing an effective method of curbing viral spread, WHO advises against the enforcement of limitations to travel and trade $(13,14)$.

In response to the COVID-19 epidemic, the Chinese educational mode is transiting online. During the outbreak, the Ministry of Education of the People's Republic of China (MOE) launched an emergency policy of Suspending Classes without Learning Termination (SCWLT) to encourage the development of online education and resource sharing (15). Online education has partly made up for the lack of classroom teaching provision during the crisis. However, deficiencies in network environments and hardware facilities are still worthy of attention. Another challenge is making a new plan for the reopening of schools. Closing schools and postponing the reopening of schools are a mitigation measure during the current COVID-19 epidemic. Although these measures are conducive to reducing the spread of the virus, they cannot be advocated as a long-term solution.
The main purpose of this paper was to summarize the online education mode and plans for schools to resume a full-time campus study adopted by the Chinese education system at all levels during the outbreak of COVID-19. An understanding and evaluation of the current condition of the Chinese education system would be of great value not only in creating further educational policies but also assisting in guiding other countries to formulate educational provision countermeasures.

\section{VIRAL TRANSMISSION AND SPREAD IN CHINA}

As of May 26, 2020, 84,543 cases of COVID-19 were confirmed in China, 68,135 of which were confined to Hubei (7). Confirmed cases have been reported in 34 provinces, cities, and in the autonomous regions of China. Figure 1A outlines the distribution of cumulative confirmed cases in China (data as of May 26, 2020).

As the mainstay of Chinese society, Chinese universities have made important contributions to emergency risk management, including the collection of alumni resources, medical rescue and emergency management, mental health maintenance, personnel mobility control, and innovation in online education models (16). However, due to the large population base of the school (including students and staff), this also creates great challenges in the prevention of the disease and management of the school. China currently has 518,800 schools at all levels, including more than 2,600 universities (excluding Hong Kong, Macao, and the Taiwan regions) (11). If we consider the region of Hubei as an example, this province has 128 colleges and universities with a total enrollment of more than 1.438 million students. Most universities in the Hubei region are in Wuhan, the provincial capital, which is the most severely affected area. Figure 1B shows the distribution of colleges and universities in various provinces, cities, and autonomous regions across the country. Moreover, the cumulative number of cases, the number of universities, and the number of university students in each province are highly correlated (Figure 1C, excluding Hong Kong, Macao, and Taiwan regions) (11).

\section{DEVELOPMENT OF AN ONLINE EDUCATION MODE}

Due to the outbreak of COVID-19, the normal teaching provision of all schools has been affected to varying degrees. During the extraordinary period of epidemic prevention and control, online education seems to make up for the lack of classroom teaching. Online education meets the needs of students and achieves highquality resource sharing. Since the MOE issued the emergency policy of SCWLT in February 2020, efforts have been made to integrate high-quality teaching resources from the country, relevant provinces, cities, and schools to provide free learning resources during the delayed school term (17). Details of how the emergency policy will be implemented and what impacts it may cause are still being debated (18). 


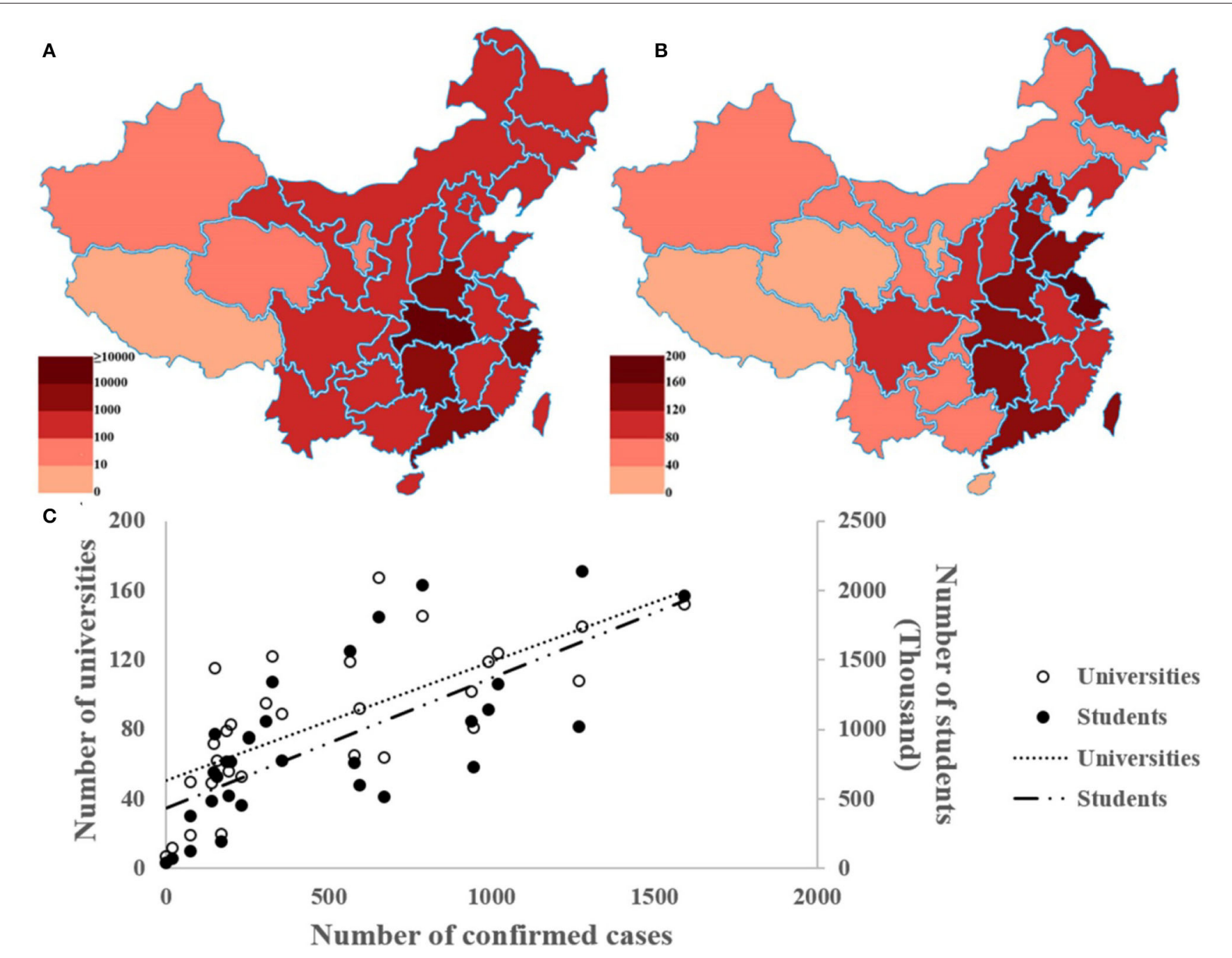

FIGURE 1 | Correlation between the cumulative case and university distribution in China. (A) The cumulative number of confirmed cases in China. (B) The distribution of universities in China. (C) The Scatterplots of cumulative diagnosis and the number of universities and students in China. This figure is original and based on data from National Health Commission of the People's Republic of China (7) and Ministry of Education of the People's Republic of China (11).

Online education can be traced back to correspondence education in the 19th century. Since the beginning of the 20th century, with the progress of communication technology, the way of learning has been constantly evolving, and the Internet and open-source learning have created an environment for large-scale distance education (18-20). There are more than 230,000 related companies engaged in the online education industry in China. In the past decade, online education companies have experienced explosive growth, and more than 60,000 related companies were further established in 2019. In the past 5 years, the concentration of online education increased, with more than 130,000 companies being established in 1-5 years, accounting for $57.6 \%$.

Online education, through the application of information technology and Internet technology for content dissemination and distance learning, has to some extent reduced the risk of epidemic spread. The number of daily active users of education and learning apps during the epidemic period rose from 87 million to 127 million, an increase of $46 \%$. Among the increase, the number of daily active users of basic education increased by more than 23 million (21). During the 8-week teaching period of the emergency policy of SCWLT, nearly 270 million students from universities, high schools, junior high schools, and primary schools in China were engaged in course learning online. At the same time, nearly 20 million teachers from universities, high school, junior high school, and primary schools performed teaching activities via the Internet. The SCWLT policy has created the largest number of online students and has refreshed the online currency of Internet use (15). Facing the big challenge of online education, whether it is a school, university, teacher, or parent, will take time to adapt to the process. Zhang et al. (18) summarized the difficulties in the implementation of the SCWLT. They suggested that there are at least five major 
A

Tibet
Qinghai
Macao
Xinjiang
Fujian
Anhui
Sichuan
Jiangxi
Shanxi
Jiangsu
Yunnan
Hunan
Jilin
Ningxia
Guizhou
Chongqing
Tianjin
Inner Mongolia
Hainan
Guangxi

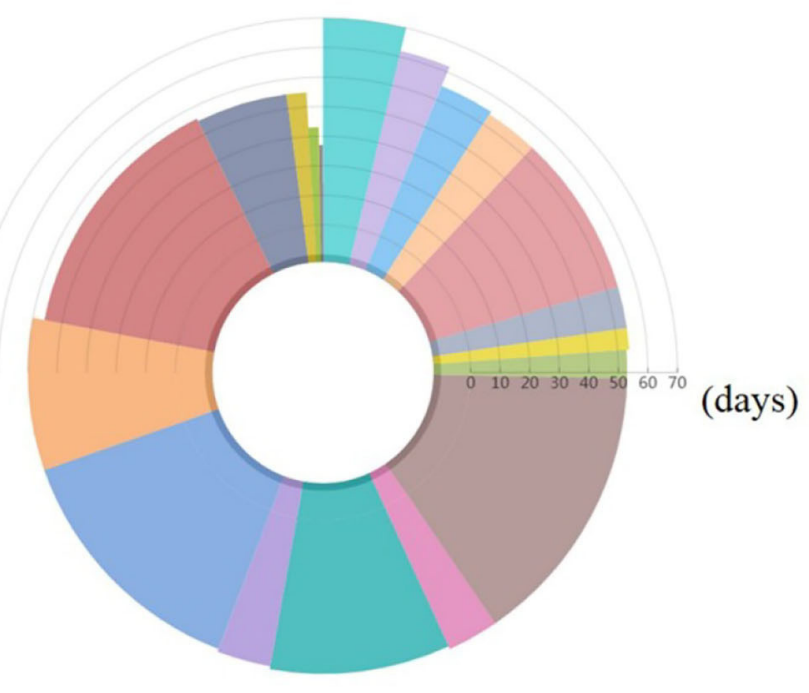

B

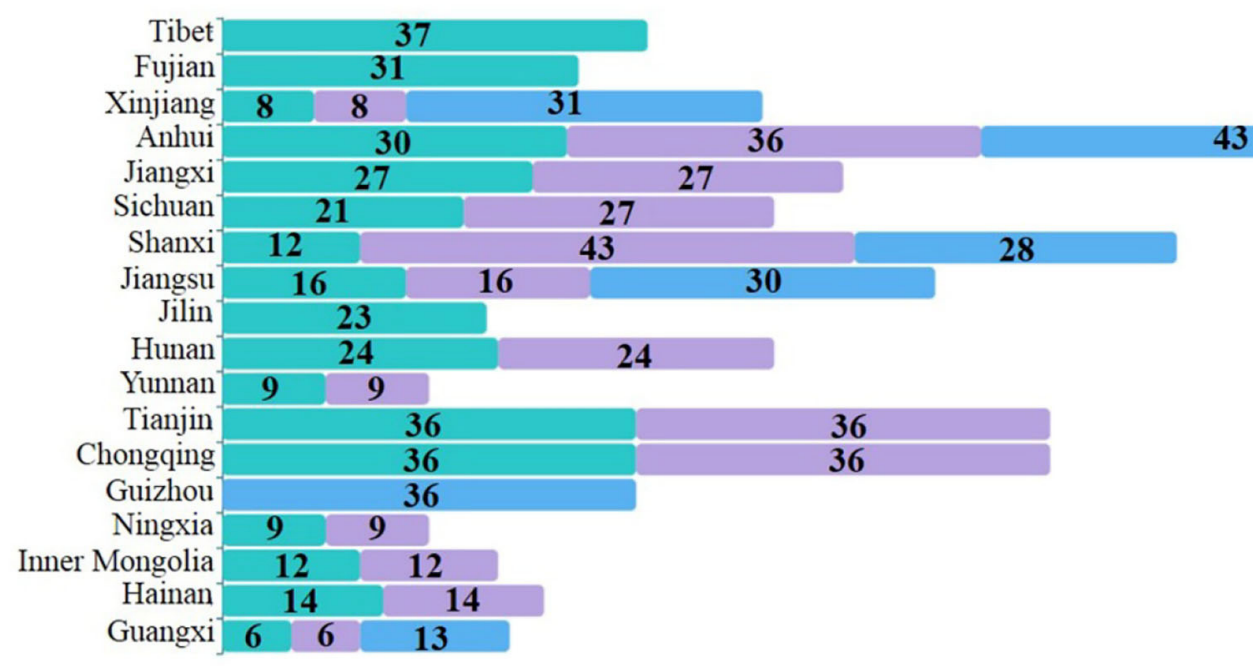

(days)

High school Middle school University

FIGURE 2 | The status of the COVID-19 and the time of back-to-school in China's provinces. (A) The time from the first diagnosis to the first time of no existing case in each province. (B) The number of days between the first time of no existing case and the reopening times of high school, middle school, and university in each province. This figure is original and based on data from National Health Commission of the People's Republic of China (7).

difficulties in policy implementation that need to be addressed, including: (1) Infrastructure constraints; (2) Low proportion and low efficiency of the use of resources; (3) The outcome effect is contingent on teachers' teaching ability and experience; (4) A variety of unpredictable teaching and learning problems; (5) It remains unclear what pedagogical method may suit the online education best.

The traditional teaching method is "passive learning," which is usually delivered in a large classroom, with little interaction. Teachers often occupy a dominant position in classroom teaching, which leads to the weakening of students' subjective innovation ability and critical spirit. Offline education mode generally has certain problems for students' including personalized learning and differentiated teaching. Online education, through the information database management technology and two-way interactive function of computer network, realizes the complete system tracking record of individual information and learning process, to provide a practical and effective way for personalized teaching. SCWLT is not a simple transition from classroom teaching/offline education to the Internet platform. Its essence is a large-scale and far-reaching practice of educational mode (15). Online education 
TABLE 1 | The detailed information about the outbreak and the time of back-to-school in China's provinces.

\begin{tabular}{|c|c|c|c|c|c|c|c|}
\hline \multirow[t]{2}{*}{ Provinces } & \multirow{2}{*}{$\begin{array}{l}\text { Cumulative } \\
\text { cases }\end{array}$} & \multirow{2}{*}{$\begin{array}{l}\text { Cumulative } \\
\text { recovery }\end{array}$} & \multirow{2}{*}{$\begin{array}{l}\text { The time of the } \\
\text { first case }\end{array}$} & \multirow{2}{*}{$\begin{array}{l}\text { The first time of } \\
\text { no existing case }\end{array}$} & \multicolumn{3}{|c|}{ The time of back-to-school } \\
\hline & & & & & $\begin{array}{c}\text { Grade } 3 \text { of high } \\
\text { school }\end{array}$ & $\begin{array}{c}\text { Grade } 3 \text { of } \\
\text { middle school }\end{array}$ & Universities \\
\hline Beijing & 593 & 509 & January 20 & - & April 27 & May 11 & - \\
\hline Tianjin & 189 & 173 & January 21 & March 15 & April 20 & April 20 & - \\
\hline Inner Mongolia & 193 & 104 & January 23 & March 18 & March 30 & March 30 & - \\
\hline Liaoning & 146 & 142 & January 22 & - & April 15 & - & - \\
\hline Jilin & 102 & 97 & January 22 & March 15 & April 7 & - & - \\
\hline Heilongjiang & 892 & 472 & January 22 & - & April 7 & April 13 & - \\
\hline Anhui & 991 & 984 & January 22 & March 8 & April 7 & April 13 & April 20 \\
\hline Fujian & 355 & 336 & January 22 & March 7 & April 7 & - & - \\
\hline Jiangxi & 937 & 936 & January 21 & March 11 & April 7 & April 7 & - \\
\hline Shandong & 787 & 765 & January 21 & - & April 15 & - & - \\
\hline Henan & 1,276 & 1,254 & January 21 & - & April 7 & - & - \\
\hline Hubei & 68,128 & 63,494 & - & - & & - & - \\
\hline Hunan & 1,019 & 1,015 & January 21 & March 14 & April 7 & April 7 & - \\
\hline Guangdong & 1,579 & 1,482 & January 21 & - & April 27 & April 27 & - \\
\hline Guangxi & 254 & 252 & January 22 & April 1 & April 7 & April 7 & April 14 \\
\hline Hainan & 168 & 162 & January 22 & March 24 & April 7 & April 7 & - \\
\hline Gansu & 139 & 137 & January 23 & - & April 9 & April 13 & - \\
\hline Qinghai & 18 & 18 & January 25 & February 21 & March 9-13 & March 16-20 & April 1-15 \\
\hline Ningxia & 75 & 75 & January 22 & March 16 & March 25 & March 25 & - \\
\hline Xinjiang & 76 & 73 & January 23 & March 8 & March 16 & March 16 & April 8 \\
\hline Taiwan & 398 & 178 & January 30 & - & - & - & - \\
\hline Hong Kong & 1,023 & 568 & January 29 & - & - & - & - \\
\hline Macao & 45 & 17 & February 2 & March 6 & - & - & - \\
\hline Total & 84,185 & 77,792 & - & - & - & - & - \\
\hline
\end{tabular}

Data from National Health Commission of the People's Republic of China and as of April 18, 2020 (7); "-": Data not presented or not applicable.

is a combination of teaching technology, education concepts, and traditional education to form a new educational mode suitable for modern educational requests. As $5 \mathrm{G}$ and artificial intelligence technologies develop, online education might effectively solve problems related to offline education. Although the key features of 5G Technology greatly increase the technology complexity, resulting in a much higher capital-intensive level compared with previous generations, most governments in developing countries tend to encourage $5 \mathrm{G}$ deployment as a strategic priority (22). Therefore, online and offline integration is imperative. At present, governments and schools are taking this opportunity and are encouraging teachers to test and validate online and offline teaching methods exploring this practice, using artificial intelligence, and big data to conduct academic analysis and educational evaluation to investigate, design, and implement future educational provision (15). 


\section{PLANS OF THE REOPENING OF SCHOOLS}

As the transmission of the virus increased, students (including all ages and educational levels) in many regions of the world were forced to stay at home. This meant that all educational provision was affected. The 77th edition of the WHO's new outbreak report shows that $90 \%$ of students and more than 150 million children and young adults worldwide have been affected by school suspensions (23). In China, the epidemic situation has improved significantly since December 31, 2019, when atypical pneumonia in Wuhan was first reported. Figure 2A shows the number of days between the first diagnosis and the first time of no existing case in each province (data as of April 18, 2020). The number of confirmed cases in Tibet reached zero within 14 days of the first confirmed cases. It took Guangxi 70 days to achieve that goal. China's students are now starting to return to campus, and the new opening plan needs further careful consideration.

With the decreasing of infection rates across the country, most provinces and cities in China decided their own time of back-to-school at all levels based on the epidemiological evidence (Table 1). Figure 2B presents the number of days between the first time of existing cases of zero and the reopening times of high school, middle school, and university in each province (data as of April 18, 2020). In China, the back-to-school plan of each province was not made by the national central government, but by the local education management department, which was distributed the power by the central government. And the education management department of each province independently made the plan according to the epidemic situation. For most provinces, grade 3 students attending high and middle school are regarded as important objectives for back-to-school plans, as they are expected to progress to higher-level education. Another important group is university graduates, who are facing the pressure of employment. The decision making on the time of back-to-school based on the following five main points;

- The status of the COVID-19 epidemic in the province, including the cumulative cases, cumulative recovery, existing cases, presence of asymptomatic infections, etc.

- Different reopening plans depending on the school and grade level. Students in grade three of high schools and middle schools, as well as fresh university graduates, are generally preferred to return to education.

- The perfection and implementation of self-quarantine and disease prevention. The specific implementation includes selfmonitored quarantine not $<14$ days after returning to school, health diagnosis of students from different areas, school disinfection work, etc.

- The connection between online courses and offline courses. Since students generally receive online education during

\section{REFERENCES}

1. Huang C, Wang Y, Li X, Ren L, Zhao J, Hu Y, et al. Clinical features of patients infected with 2019 novel coronavirus in Wuhan, China. Lancet. (2020) 395:497-506. doi: 10.1016/S0140-6736(20)30183-5 school closure, they need to make a transition to offline education after returning to school. The educational experience should be of high quality and the quality of teaching should be ensured.

- The establishment of multiple collaborative governance mechanisms including "government-family-school-society." The formulation of the back to school plan is not only realized by the school but also needs the resource and information sharing between the government, family, and society.

Large population movements, particularly of college students from all over the country that are returning to school, and detection of possible transmission by asymptomatic carriers will also be a challenge to prevent and control further COVID-19 infections (24). The nation needs to be prepared for a possible rebound of the outbreak (5), especially in schools, with disastrous consequences and health implications that want to be avoided.

\section{CONCLUSIONS}

Globally, the number of COVID-19 confirmed cases is still increasing. Although isolation alone may not be enough to prevent the spread of the epidemic, it is undoubtedly one of the most economical and effective ways to minimize its risk. For educational systems at all levels, online education may be an effective way to compensate for the lack of classroom teaching during the epidemic. However, issues such as the network environment, hardware equipment, and educational quality and educational experience for the students deserve special attention. From the perspective of the safety of teachers and students, whether it is primary, secondary school, or university, the organization of educational establishments reopening strategies need careful consideration.

\section{AUTHOR CONTRIBUTIONS}

XC, DS, and YS conceived the presented idea, developed the framework, and wrote the manuscript. MR, GF, JB, and YG provided critical feedback and contributed to the final version. All authors have read and agreed to the published version of the manuscript.

\section{FUNDING}

This study was sponsored by the Key Project of the National Social Science Foundation of China (19ZDA352), National Natural Science Foundation of China (No. 81772423), NSFCRSE Joint Project (81911530253), National Key R\&D Program of China (2018YFF0300905), and K. C. Wong Magna Fund in Ningbo University.
2. World Health Organization. Naming the Coronavirus Disease (COVID-19) and the Virus That Causes It. World Health Organization (2020). Available online at: https://www.who.int//hh/emergencies/diseases/novel-coronavirus2019/technical-guidance/naming-the-coronavirus-disease- (covid-2019)and-the-virus-that-causes-it (accessed March 6, 2020). 
3. Song Y, Ren F, Sun D, Wang M, Baker JS, István B, et al. Benefits of exercise on influenza or pneumonia in older adults: a systematic review. Int J Environ Res Public Health. (2020) 17:2655. doi: 10.3390/ijerph17082655

4. McKibbin W, Fernando R. The global macroeconomic impacts of COVID-19: seven scenarios. SSRN Electron J. (2020) 19. doi: 10.2139/ssrn.3547729

5. Novel Coronavirus Pneumonia Emergency Response Epidemiology Team. The epidemiological characteristics of an outbreak of 2019 novel coronavirus diseases (COVID-19) in China. Chin J Epidemiol. (2020) 41:145-51. doi: 10.3760/cma.j.issn.0254-6450.2020.02.003

6. Liu Y, Gayle AA, Wilder-Smith A, Rocklöv J. The reproductive number of COVID-19 is higher compared to SARS coronavirus. J Travel Med. (2020) 27:taaa021. doi: 10.1093/jtm/taaa021

7. National Health Commission of the People's Republic of China. COVID19 Real-Time Big Data Report. National Health Commission of the People's Republic of China (2020). Available online at: https://voice.baidu.com/act/ newpneumonia/newpneumonia/?from=osari_pc_3 (accessed May 26, 2020).

8. The New York Times. Coronavirus in New York: Lunar New Year events canceled over fears. The New York Times. (2020). Available online at: https://www.nytimes.com/2020/01/29/nyregion/coronavirus-nyc. html (accessed January 29, 2020).

9. Wu Z, McGoogan JM. Characteristics of and important lessons from the coronavirus disease 2019 (COVID-19) outbreak in China: summary of a report of 72314 cases from the Chinese center for disease control and prevention. JAMA. (2020) 323:1239-42. doi: 10.1001/jama.20 20.2648

10. Zhang C, Chen C, Shen W, Tang F, Lei, H, Xie, Y, et al. Impact of population movement on the spread of $2019-\mathrm{nCoV}$ in China. Emerg Microbes Infect. (2020) 9:988-90. doi: 10.2139/ssrn.3546090

11. Ministry of Education of the People's Republic of China. Statistical Bulletin on the Development of National Education in 2018. Ministry of Education of the People's Republic of China (2020). Available online at: http://www.moe. gov.cn/jyb_sjzl/sjzl_fztjgb/201907/t20190724_392041.html (accessed July 24, 2019).

12. Cohen J, Kupferschmidt K. Mass testing, school closings, lockdowns: countries pick tactics in "war" against coronavirus. Science. (2020). doi: 10.1126/SCIENCE.ABB7733 Available online at: https://www.sciencemag.org/news/2020/03/mass-testing-school-closings-lock downs-countries-pick-tactics-war-against-coronavirus (accessed March 18, 2020).

13. Sohrabi G, Alsafi Z, O’Neill N, Khan M, Kerwan A, Al-Jabir A, et al. World Health Organization declares global emergency: a review of the 2019 novel coronavirus (COVID-19). Int J Surg. (2020) 76:71-6. doi: 10.1016/j.ijsu.2020.02.034

14. Madhav N, Oppenheim B, Gallivan M, Mulembakani P, Rubin E, Wolfe N. Pandemics: risks, impacts, and mitigation. In: Jamison DT, Gelband H, Horton S, editors. Disease Control Priorities: Improving Health and Reducing Poverty. 3rd ed. Washington, DC: The International Bank for Reconstruction and Development/The World Bank (2017). p. 316-45.
15. Zhou L, Li F, Wu S, Zhou M. "School's out, but class's on", the largest online education in the world today: taking China's practical exploration during the COVID-19 epidemic prevention and control as an example. Best Evid Chin Edu. (2020) 4:501-19. doi: 10.15354/BECE.20.AR023

16. Wang C, Cheng Z, Yue XG, McAleer M. Risk management of COVID19 by universities in China. J Risk Financial Manag. (2020) 13:36. doi: $10.3390 / \mathrm{jrfm} 13020036$

17. Ministry of Education of the People's Republic of China. Notice on Work Arrangements for "Suspending Classes Without Stopping Learning" During the Delayed Start of Primary and Middle Schools. Ministry of Education of the People's Republic of China (2020). Available online at: http://www.moe.gov. $\mathrm{cn} /$ srcsite/A06/s3321/202002/t20200212_420435.html (accessed February 12, 2020).

18. Zhang W, Wang Y, Yang L, Wang C. Suspending classes without stopping learning: China's education emergency management policy in the COVID19 outbreak. J Risk Financial Manag. (2020) 13:55. doi: 10.3390/jrfm130 30055

19. Volery T. Online education: an exploratory study into success factors. J Educ Comput Res. (2001) 24:77-92. doi: 10.2190/F0DY-BNYJ-18RB-NNNY

20. Orozco-Messana J, Martínez-Rubio JM, Gonzálvez-Pons AM. Sustainable higher education development through technology enhanced learning. Sustainability. (2020) 12:3600. doi: 10.3390/su12093600

21. People's Daily Online. Improving the quality of online education requires concerted efforts. People's Daily Online. (2020). Available online at: http:// capital.people.cn/n1/2020/0323/c405954-31644107.html (accessed March 23, 2020).

22. Forge $\mathrm{S}, \mathrm{Vu} \mathrm{K}$. Forming a $5 \mathrm{G}$ strategy for developing countries: a note for policy makers. Telecommun Policy. (2020) 44:101975. doi: 10.1016/j.telpol.2020.101975

23. World Health Organization. Coronavirus Disease 2019 (COVID-19) Situation Report-77. World Health Organization (2020). Available online at: https:// www.who.int/docs/default-source/coronaviruse/situation-reports/20200406sitrep-77-covid-19.pdf?sfvrsn=21d1e632_2 (accessed April 6, 2020).

24. Bai Y, Yao L, Wei T, Tian F, Jin DY, Chen L, et al. Presumed asymptomatic carrier transmission of COVID-19. JAMA. (2020) 323:1406-7. doi: $10.1001 /$ jama.2020.2565

Conflict of Interest: The authors declare that the research was conducted in the absence of any commercial or financial relationships that could be construed as a potential conflict of interest.

Copyright (C) 2020 Cen, Sun, Rong, Fekete, Baker, Song and Gu. This is an open-access article distributed under the terms of the Creative Commons Attribution License (CC $B Y)$. The use, distribution or reproduction in other forums is permitted, provided the original author(s) and the copyright owner(s) are credited and that the original publication in this journal is cited, in accordance with accepted academic practice. No use, distribution or reproduction is permitted which does not comply with these terms. 